\title{
CONRAD OF QUERFURT AND PETRARCH ON THE LOCATION OF THE VERGILIAN UNDERWORLD
}

(With an appendix on Petrarch's Avernian Sources)

In an excellent article on Petrarch's own manuscript copy of Vergil, the Ambrosiano of Milan (Bibl. Ambros. S.P. arm. 10 sc. 27, formerly A 49 inf.), which has the commentary of Servius alongside the text of Vergil, Michele Feo was the first to have pointed out that Petrarch derived from Servius his beliefs that (i) Homer had long before Vergil described the bay of Pozzuoli, to which he brought Odysseus; and that (ii) Misenus was sacrificed by Aeneas to the infernal deities in the same place as Elpenor was by Odysseus, in an analogous sacrificial ritual. ' The present paper, in recognizing Petrarch's reliance upon Servius, has two aims: firstly, to investigate Petrarch's dependence upon Servius from another perspective by arguing that Petrarch adopted - but may have erred over - the Servian location of Vergil's 'catabatic' cave through which Aeneas and the Sibyl descended into the Land of the Dead - a point on which Feo did not comment - and, secondly, to provide a new line of argument on Petrarch's location of the Vergilian underworld that strengthens Feo's further claim that Petrarch's description of the Avernian region was influenced by Conrad of Querfurt as well as by Servius.

\section{THE VERGILIAN, SERVIAN AND TOPOGRAPHICAL BACKGROUND}

According to Vergil, the cave through which Aeneas and the Sibyl made their descent to the underworld was concealed by the darkness of a lake within the shady Avernian grove (Aen. 6. 118):

Spelunca alta fuit vastoque immanis hiatu, scrupea, tuta lacu nigro nemorumque tenebris. (Aen. 6. 237-8).

The lake, called lacus Avernus, is to be found within the Phlegraean Fields midway between Roman Puteoli (modern Pozzuoli) and Cumae in southern Italy (Fig. 1).

Vergil's description of the imaginary cave at Avernus may have been influenced by either or both of two immense tunnels cut in precisely this location on the southern and northwestern shores through the once heavily wooded crater-rim surrounding Avernus. Neither was a cult site, but local tradition, perhaps taking a hint from Vergil's description of the cave 'with the huge gaping mouth' (above, vs. 237), gave the name 'Grotta della Sibilla' to the tunnel on the southern shore. This 'Grotta', with its ancient mouth, now partly blocked up with later masonry, bores through the crater-height known on this side of the lake as Monte della Ginestra and emerges after $200 \mathrm{~m}$ to overlook Lake Lucrinus's northern shore.

${ }^{1}$ M. Feo, 'Inquietudini filologiche del Petrarca: il luogo della discesa agli inferi (storia di una citazione)', Ilalia Medioevale e Umanistica 17 (1974), 115-83, at p. 152. 


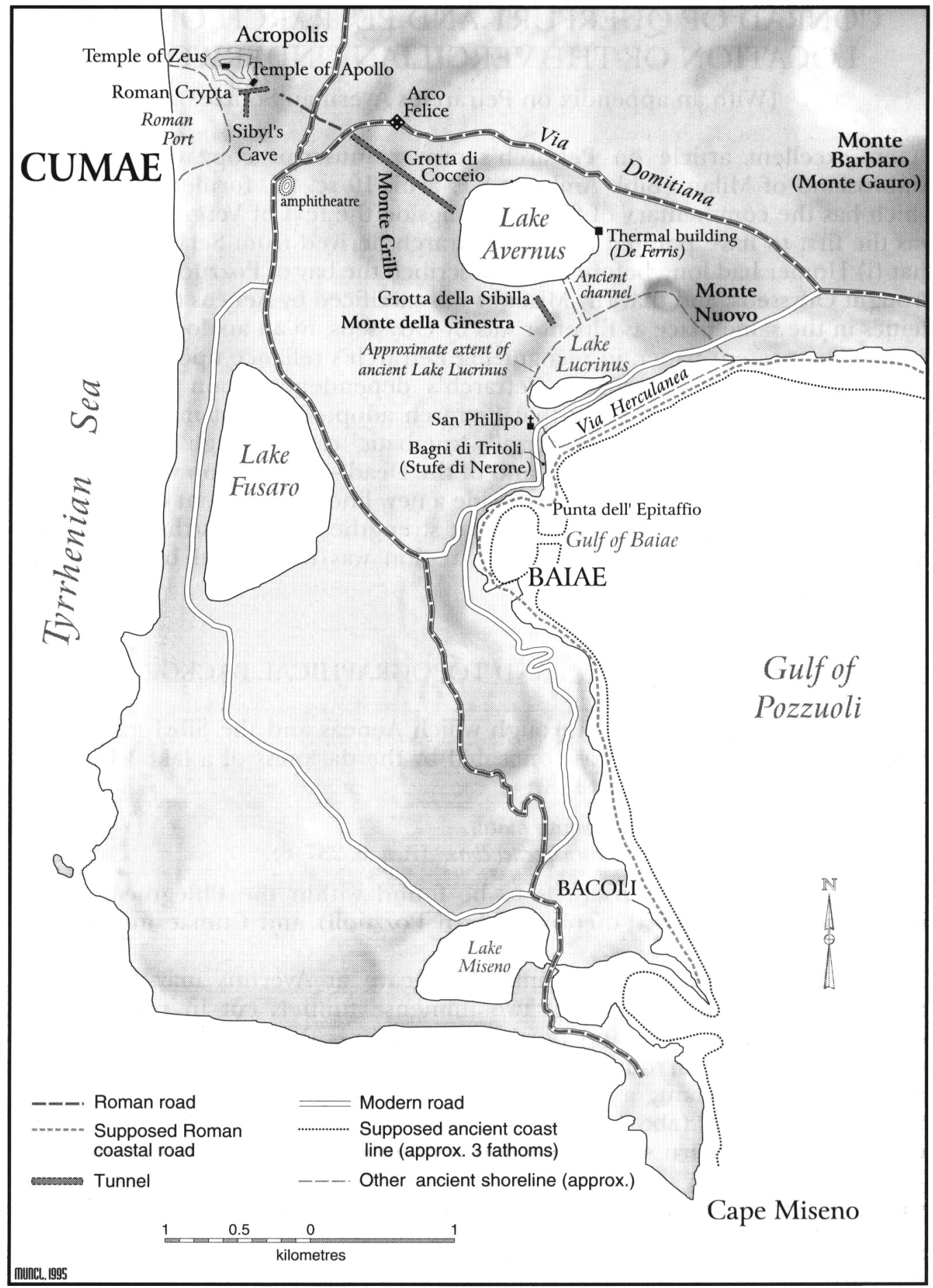

FIg. 1. The Phlegraean Fields from Cumae to Monte Barbaro. 
The traditional identification of Vergil's catabatic cave with the Grotta is at least as old as Vergil's fourth-century commentator Servius. In a note upon the 'infernal lakes' which the seer Helenus predicted Aeneas would pass as he sailed up the coast to Cumae, Servius remarked (ad Aen. 3. 386) that by inferni lacus Vergil 'means Lucrinus and Avernus, between which there is the cave through which the descent to the lower world took place; whence he called the lakes infernal': 'Lucrinum et Avernum dicit, inter quos est spelunca, per quam ad inferos descendebatur; unde eos dixit infernos'. And in a note on the spelunca of Aen. 6. 237 Servius observed that this Avernian cave was "where the descent to the lower world took place, not where the Sibyl prophesied': 'qua ad inferos descendabatur, non ubi fuerat Sibylla vaticanata'. Servius therefore rightly distinguished the catabatic cave at Avernus described by Vergil at Aen. 6. 237ff. from the oracular cave on the Cumaean acropolis described at Aen. 6. 10-11 and 42ff.

In a separate article, ${ }^{2}$ designed to show the cultural history of the Avernian cave mentioned by Servius, from its original purpose as Roman military tunnel to the Sibyl's mythical cave and finally therapeutic spa, I have provided fuller details on both of the tunnels leading from Avernus and on a third tunnel beneath the acropolis of Cumae (Fig. 1). It is likely that all three tunnels were built by Agrippa's engineer and architect Lucius Cocceius Auctus as part of the military installation transforming lake Avernus into a strategic naval base called Portus Julius for Octavian in 37-36 BC. The three tunnels facilitated communication by land between the new naval port and the Tyrrhenian sea to the west and the gulf of Pozzuoli to the south. The tunnel on the northwestern shore of Avernus alone takes the name of its architect and is called the Grotta di Cocceio. It runs for about a kilometre beneath Monte Grillo and is by far the longest of the three tunnels. Petrarch and Conrad, as we shall see, were familiar with the area. This outline of the topography will, it is hoped, assist in the understanding of their testimony, which follows.

\section{THE ARGUMENT}

In his letter Rerum familiarium libri 5.4 to Giovanni Colonna, composed after his second visit to the Naples area in the autumn of 1343, when serving on missions from Cardinal Colonna and Pope Clement VI, ${ }^{3}$ Petrarch wrote of the Homeric scene in the Avernian region and described the alleged Vergilian catabatic cave (as well as the Sibyl's 'home') as follows:" 'Vidi loca a Virgilio et, quod maxime

\footnotetext{
${ }^{2}$ R.J. Clark, 'The Avernian Sibyl's cave: from military tunnel to mediaeval spa', forthcoming in Classica et Mediaevalia 47 (1996).

${ }^{3}$ For the date and the missions see E.H. Wilkins, Studies in the Life and Works of Petrarch (Camb. Mass., 1955), 11-12, with further details in n. 10 below. Petrarch first visited the area in 1341, on the occasion of the pre-coronation examination by King Robert of Naples (Wilkins, p. 8).

${ }^{4}$ Petrarch, Fam. 5. 4, ed. V. Rossi, Francesco Petrarca: Le Familiari (Florence, 1934), II, 10-14, at p. 11. I have recuperated from Rossi's apparatus criticus the $B$ text preserving Petrarch's reference to Homer ('et, quod ... descripia ...'), which the 1368 edition ( $\alpha$ ) supresses. The Basle 1554 edition is notoriously inaccurate, but it preserves the full text at this point (Opera, II. 713).
} 
mireris, ab Homero multum ante descripta ... vidi Averni et Lucrini lacus, Acherontis quoque stagnantes aquas ... vidi Sibylle patriam ac domum, et horrificum illud specus, stultis irremeabile, doctioribus inaccessum?.

In his Itinerarium Syriacum Petrarch did not overtly mention the Avernian cave, but he clearly alluded to it when describing the 'entrance of Dis, the threshold of no return':

Sunt qui putent Misenum ibi peremplum ab Enea diis infernis sacra facturo que, ut asserunt, absque humana cede fieri nequeunt ...; esse aulem huiuscemodi sacris apta loca, quod ibi sint Avernus atque Acheron Tartarea nomina, ibi Ditis ostia, limen irremeabile, et illic facilis descensus Averni, de quo loquitur poeta, quem patentem diebus dixit ac noctibus ... Hic Sibille Cumane domus maxima, super horrentem Averni ripam cernitur, iam senio semiruta, habitatore quidem nullo, sed variarum volucrum nidus frequens. In eodem flexu fontes calidi tepentesque insignius quam in alia parte nostri orbis erumpunt ...

Here Petrarch has used words that recall Vergil's at Aen. 6. 126-7 to connect 'Dis's threshold of no return' with 'Avernus's easy descent open day and night'. When Petrarch referred to the alleged Vergilian underworld cave - first in Fam. 5. 4 as 'horrificum illud specus, stultis irremeabile, doctioribus inaccessum', and then in the Itinerarium Syriacum as 'Ditis ostia limen irremeabile, et illic facilis descensus Averni' - which cave did he have in mind? Let us begin by turning to an author whose view he knew well.

Servius, in his above quoted note on Aen. 3. 386, recorded the belief that Vergil's catabatic cave of Aen. 6. 237 was located between Lucrinus and Avernus. He identified it, in other words, with the Roman military tunnel, which is the only cave between the two lakes. This is the cave known in tradition as the Grotta della Sibilla. We know that Petrarch took careful note of Servius's location of the cave 'Lucrinum et Avernum ..., inter quos est spelunca, per quam ad inferos descendebatur', because in the bottom margin of fol. 95v of his manuscript copy of Vergil, the Ambrosiano, Petrarch annotated Servius's word spelunca (ad Aen. 3. 386) as follows: ' 'Spelunca hec in latere montis est, qui nunc Barbarus dicitur, ubi ego ipse ante paucos annos fui. Cuius in epistolis meis memini, latius describens locum. Huius etiam in $6^{\circ}$ mentionem facit'. Of particular interest for us is Petrarch's remark that this cave is 'in the side of the mountain now called Barbarus', which he says he visited 'a few years earlier'. And he claimed to have mentioned the cave in a letter in which he 'amply describes the place'.

The epistolae here referred to must have been epistolae metricae rather than any letter in prose. Petrarch did not mention any cave within the flank of Monte Barbaro in Fam. 5. 4 or in his later Itinerarium Syriacum, from which all pertinent passages have been extracted above. But the name 'Mons Barbarus' does appear in Metr. II. 15, written to Rinaldo Cavalchini during the November and

\footnotetext{
${ }^{5}$ Francesco Petrarca, Itinerario in Terra Sancta, ed. F. Lo Monaco (Bergamo, 1990), 54-6.

${ }^{6}$ Petrarch cross-referenced his postilla to Servius's word spelunca with the matching notation marks $\infty$. All is legible in the manuscript's facsimile Francisci Pelrarcae Vergilianus codex ad Publii Vergilii Maronis diem natalem bis millesimum celebrandum quam simillime expressus atque in lucem editus ... praefatus est Iohannes Galbiati etc. (Mediolani, 1930), fol. 95v.
} 
December immediately following his visit to the area in the autumn of 1343 , which moreover amply described the area (latius describens locum), more so than the prose pieces. This metrical letter, then, is the letter to which he referred in his 'postilla' on Servius. We may infer from the fact that Petrarch said his visit occurred a 'few years prior' to his annotation on Servius (ante paucos annos), that he journeyed to the Phlegraean Fields without his copy of Vergil; he may have written his note before composing the Itinerarium Syriacum in March 1358, nearly fifteen years after his visit. It may be added that Petrarch's allusion in his third and final sentence to Servius's mention of the cave in the Sixth Book probably refers to Aen. 6. 237, where, as we have seen, Servius distinguished between the catabatic and oracular caves. It is possible that Petrarch may also have had in mind Servius's extensive topographical (and Homeric) remarks on Vergil's 'Acheron' at Aen. 6. 107, where, in the lower left margin of fol. 131v of his manuscript copy of Vergil, Petrarch wrote a second postilla on Servius that is contemporary with the first, to judge from Petrarch's matching phrase ante annos paucos. It reads: 'Descriptio loci quem ante annos paucos diligentissime contemplatus sum oculata fide'. At all events, the pertinent passage describing the cave within Monte Barbaro in Petrarch's metrical letter (Metr. II. 15) is as follows: ${ }^{7}$

Mons pervius imos

40

inde petit manes, et nomine barbarus et re, si comperta ferunt: ego nam procul atria Ditis contentus vidisse fui, irremeabile limen: praeter enim quod fama vetus, quod carmina terrent, huc rudis agricola timet, huc accedere pastor, nauta nec aequorea, sitiens telluris, ab unda hoc audet calcare solum. Vicinia narrat nescio quos, auri stimulante cupidine, nuper (quod curvis sine fine putant latitare cavernis) irreducem tentasse aditum, votoque potitos

forsitan, atque atrae tentos dulcedine vallis, erratis seu forte viis, seu compede mortis,

infernum coluisse larem, civesque manere tartareos.

Petrarch's portrayal here of the subterranean regions of Monte Barbaro bears striking resemblance to those described in a letter written in 1195 by Conrad of Querfurt, Chancellor of the Swabian Emperor Henry VI and also Bishop of Hildesheim. The letter was addressed to his friend Arnold of Lübeck, the prior of the abbey at Hildesheim. It contains Conrad's observations on the journey he had made during the preceding year from the Alps to Sicily on his mission to conquer Naples at the behest of the Emperor. As befits one who had been chosen by Frederick Barbarossa to educate the future Henry VI - he had been his tutor - Conrad quoted Vergil and other poets. He also showed a fond

${ }^{7}$ D.R. Rossetti (ed.), E. Petrarca: Poëmata minora III (Milan, 1834), 166-8. I have corrected imas in verse 40 , but have not restored Petrarch's spelling, which Rossetti classicized. 
fascination for the curiosities of the Naples region he so ruthlessly destroyed. About Monte Barbaro he wrote: ${ }^{8}$

\begin{abstract}
Est ibidem mons Barbarus, ad quem per viam subterraneam per medium maximi montis accessimus per tenebras infernales, tamquam ad inferos descensuri. In quo monte, in ipsis montis visceribus, maxima sunt palatia et vici, quasi maxime civitatis, subterranei et fluvii ferventis aque subterranei, quos quidam ex nostris viderunt et sub terra quasi per spatium duorum miliarium processerunt. Ibidem thesauri septem regum asseruntur repositi, quos demones custodiunt in ereis ymaginibus inclusi, diversas terribiles ymagines pretendentes, quidam arcu tenso, quidam gladiis, quidam aliis comminantes.
\end{abstract}

Citing three additional sources for this legend of the treasures concealed within an Italian mountain - namely the Gesta regum Anglorum (1120) by William of Malmesbury, the Speculum historiale (1244) by Vincent de Beauvais, and the Reductorium morale by Pierre Bersuire (1290-c. 1362), all of which leave the mountain unnamed - Feo observed that Petrarch alone agreed with Conrad of Querfurt in identifying the mountain as Monte Barbaro, and inferred from this remarkable point of contact Petrarch's direct dependence upon Conrad. ${ }^{9}$

What Feo did not point out is the connection between all three of Petrarch's descriptions. In Fam. 5. 4 Petrarch claimed to have seen (vidi) the Vergilian cave. In Metr. II. 15.42-3, however, he acknowledged that he saw the infernal threshold within the cave actually only from a distance - 'ego nam procul atria Ditis/ contentus vidisse fui, irremeabile limen'. He did not venture too close to these 'halls of Dis with its threshold of no return' - doubtless because the cave beneath the mountain with the buried treasure was also for Petrarch the very Hades-entrance described in Fam. 5. 4 as 'that awesome cave without return for the foolish and without access for the wise' (Latin text quoted above at n. 4). For the identification of its infernal aspect Petrarch made clear that he relied on others (si comperta ferunt). That he believed this cave to be the Hades-entrance is confirmed by similar language in the Itinerarium Syriacum, where he again mentioned the Ditis ostia limen irremeabile in connection with the famed 'facilis

${ }^{8}$ Epistola Conradi cancellarii = I.M. Lappenberg (ed.), Arnaldi abbatis Lubecencis Chronica Slavorum, Bk V ch. 19, in G.H. Pertz (ed.), Monumenta Germaniae Historica: Scriptores (Hannover, 1869), XXI. 192-6, at p. 196. Conrad's repetitive use of 'ibidem' is often very loose (see further $n$. 15 below) and in this paragraph (which follows immediately upon the one referring to Ischia partially quoted at $\mathbf{n} .14$ below) it means no more than the general area of Aeneas's descent within the Phlegraean Fields.

${ }^{9}$ Feo, 'Inquietudini filologiche del Petrarca' (above, n. 1), 170, citing William of Malmesbury, De gestis regum Anglorum, 2.170 (on 'Quomodo quidam thesauros Octoviani quaesierunt' ) ed. D.G. Waitz, in G.H. Pertz (ed.), Monumenta Germaniae Historica: Scriptores (Hannover, 1852), X. 463-4 = W. Stubbs (ed.) in Rerum Britannicarum Medii Aevi Scriptores (London, 1887; Kraus repr. 1964), XC. 198-201; Vincent de Beauvais, Speculum historiale 24.100, ed. by the Benedictines of Douai (Douai, 1624), IV. 998; Pierre Bersuire, Reductorium morale 24. 72.7 (Venice, 1583), II. 690. Feo here warned against confusing this legend with other legends locating the subterranean treasure in Sicily or Rome (for example, William of Malmesbury, ed. Waitz in Pertz, II.169), and on p. 168 mentioned a second point of contact between Petrarch and Conrad, which is taken up below, in the Appendix. 
descensus Averni'. And on fol. 95v in his copy of Vergil, Petrarch, as we have seen, explicitly connected the cave of Metr. II. 15 with Servius's location of the Vergilian spelunca 'through which the descent to the lower world took place'. The problem is that Petrarch located this cave within Mons Barbarus nearly $2 \mathrm{~km}$ to the northeast of Avernus (Fig. 1), whereas Servius said it was between the Avernian and Lucrine lakes.

Petrarch's location of the Vergilian Hades-entrance within this mountain in Metr. II. 15 clearly contradicts its famed proximity to Avernus, asserted not only by Petrarch himself in Fam. 5. 4 and in the Itinerarium Syriacum - and, we might add, by Petrarch also in the metrical letter Metr. II. 7, written just before his visit in 1343, inviting Barbato of Sulmona to give him an archaeological tour of the area and show him the "configuration of hideous Avernus, from which a path leads to the Stygian abodes' ('faciemque informis Averni, / Unde iter ad Stygias sedes', vss. 43-4) ${ }^{10}$ - but also by Vergil and Servius as well. In fact, Monte Barbaro is not renowned for the subterranean caves within it. The latest archaeological report on its occupancy during the pre-Roman and Roman periods speaks of sparse remains of houses and thermal establishments, but mentions nothing of ancient subterranean perforations. ${ }^{11}$ Yet Petrarch wrote of a mountain that was perforated (pervius), that is to say pierced through with one or more passages. Conrad said that in its bowels there was practically an underground city with palaces and city-sections and boiling streams, and 'a subterranean passage that to those of us who made the journey seemed like two miles long' ('quidam ex nostris ... sub terra quasi per spatium duorum miliarium processerunt'). The only hill in the Avernian area of the Phlegraean Fields which can match this description is Monte Grillo, which is pierced through by the Grotta di Cocceio with its various offshoots for about a kilometre in length. The nearby Grotta della Sibilla, being about $200 \mathrm{~m}$ in length, is much shorter. It seems best then to infer that Conrad first - and erroneously - gave the name Monte Barbaro to the height called Monte Grillo, traversed by the Grotta di Cocceio, on the northwest shore of Avernus, and that Petrarch followed Conrad in misnaming the height, which he unquestionably understood to be beside Avernus.

It is worth adding that Monte Barbaro extends around an ancient volcano originally called Monte Gauro, the similarity in name being perhaps the source of confusion by Conrad (or some predecessor) with Monte Grillo. Feo did not mention the Neapolitan historiographer Benedetto di Falco's version (1549) of the legend actually associating the treasure-cave with a Spanish knight called Pietra di Pace. In this late reworking of the legend, the Spanish knight was

${ }^{10}$ D.R. Rossetti (ed.), F. Petrarca: Poëmata minora II (Milan, 1831), 16. As Wilkins, Studies in the Life and Works of Petrarch (above, n. 3), 220, said, this letter, in which Petrarch urged Barbato to be his guide in a tour of Baiae and near-by places, was written in Naples prior to 23 November, 1343, the date on which Petrarch's excursion with Barbato (and Giovanni Barrili) was made, as we learn from Fam. 5. 4. Wilkins therefore has supposed Metr. II. 7 to have been written within the period mid-October-22 November 1343'.

${ }^{11}$ See P. Amalfitano, G. Camodeca and M. Medri (eds), I Campi Flegrei: un itinerario archeologico (Venice, 1990), 151 and 153. 
responsible for having excavated the interior of the mountain. Convinced that treasure lay concealed within Monte Barbaro, the Spanish knight expended all his fortune on paying magicians and necromancers to help him find it. But the object of his search eluded him, despite his magical excavation of the Grotta, which was named after him the 'Grotta della pace'. ${ }^{12}$ Now since the Grotta di Cocceio is called the 'Grotta della pace' in popular legend, ${ }^{13}$ we know that at some point Monte Grillo was mistaken for Monte Barbaro. How early this confusion was made is unknown, but it seems certain that Conrad was describing the Grotta di Cocceio, and that Petrarch was misled by Conrad over the name of the mountain at the Avernian lakeside.

Even so, it is curious that Petrarch should have identified the Vergilian Hades-entrance with the Grotta di Cocceio on Avernus's northwest shore looking towards Cumae. For in his postilla on Servius ad Aen. 3. 386 Petrarch accepted Servius's location of it between Avernus and Lucrinus, that is to say in the Grotta della Sibilla on the southern shore of lake Avernus looking towards Lucrinus; and in his subsequent postilla on Servius ad Aen. 6. 107 Petrarch asserted that he surveyed the area most attentively (diligentissime contemplatus sum). We can infer either that Petrarch erred as far as Servius is concerned and understood the Grotta di Cocceio to be Vergil's catabatic cave, or that he located it where Servius said and mistakenly thought that Conrad was describing the Grotta della Sibilla. In this case Petrarch transferred the legend from the longer to the shorter of the two tunnels beside Avernus and applied the name of Mons Barbarus to Monte della Ginestra on the southern side of the lake. Petrarch's assertion that he saw the halls of Dis only from a distance (procul) in Metr. II. 15.42 suggests that he did not venture to visit all parts of the cave and so may not have known the relative lengths of the two tunnels.

In one regard Petrarch showed that he knew better than Conrad. For Conrad located Aeneas's descent on the island of Ischia opposite Cumae: ${ }^{14}$ 'Est ante civitatem eandem insula, que vulgo Iscla dicitur, in qua ignis cum fumo sulphureo evomitur continuus ... Ibi firmissime asseritur os esse inferni et ibi esse loca penalia referuntur. Ibi etiam Eneas fingitur ad inferna descendisse'. The fact that Conrad placed Aeneas's descent in Ischia and not beside Avernus explains why he did not conflate the treasure-cave with the catabatic cave, as Petrarch did. Conrad invested the former with the darkness of the underworld (tenebras infernales) but

${ }^{12}$ Benedetto di Falco, Descrittione dei luoghi antichi di Napoli e del suo amenissimo distretto, ed. T.R. Toscano, G. Toscano and M. Grippo (Cuen, 1992), 165-6 = first known ed. Ioan. Paulo Sugganappo (Napoli, 1549; copies in Bibl. Univ. di Napoli, Rari 32, and Bibl. Vat. R.G. Storia VI.169), fols G6v-G7r. (T.R. Toscano, pp. 13ff. has shown why the widely alleged 1539 edition has never existed). By contrast, Benedetto di Falco elsewhere (pp. 131-2 = fols B7v-B8r in the 1549 edition) adopted Petrarch's view in Itinerarium Syriacum (ed. Lo Monaco (above, n. 5), 58) that only the common man would believe that Vergil used magic powers to make the tunnel through the Crypta Neapolitana described below at n. 19.

${ }^{13}$ Reported by, for example, A. Maiuri, The Phlegraean Fields (third edition) (Rome, 1958), 142, and Amalfitano, Camodeca and Medri, I Campi Flegrei (above, n. 11), 178.

${ }^{14}$ Epistola Conradi cancellarii, ed. Lappenberg (above, n. 8), XXI. 196. 
said only that it produced the effect 'as though we were about to descend to the world of shades' ('tamquam ad inferos descensuri'). For the same reason Conrad held that the Sibyl's dwelling at Avernus was separate from the place of descent. He called it her 'palace' and described it as follows: ${ }^{15}$ 'Ibidem est palatium Sybille, operosis constructum edificiis, in quo est balneum, quod hodiernis diebus balneum Sybille nuncupatur'.

These two peculiarities in Conrad's letter seem to account in part for two quite large unique features in Petrarch. First, Petrarch conflated, as Conrad did not, Vergil's catabatic cave at Avernus with the legendary treasure-cave and the name of its mountain, deriving both of these notions from Conrad. At the same time Petrarch also looked at Vergil's imaginary cave through Servian eyes and located it in a real cave - whether in the Grotta della Sibilla (the site indicated by Servius) or in the Grotta di Cocceio (the site of Conrad's treasure-cave) we cannot be sure. Second, Petrarch seems to have derived from Conrad, too, the notion (rare in his day) that the Sibyl dwelt apart from the place of descent, though Petrarch, unlike Conrad, identified both the Sibyl's home and the catabatic cave on the lakeside. Since the Sibyl's home is strictly a separate topic from the Vergilian underworld, further discussion of it is taken up in the Appendix devoted to assessing more fully Petrarch's debt to Conrad.

RAYMOND J. CLARK

\section{APPENDIX 1. PETRARCH'S AVERNIAN SOURCES}

\section{THE BATHS AT TRITOLI}

In note 9 of this paper attention was drawn to the likelihood of a second point of contact between Conrad and Petrarch, one which Feo had observed. The pertinent passages are reproduced here for convenience, with the purpose of providing the reader with the opportunity to assess their closeness. Both Conrad and Petrarch described a series of sculptured figures decorating a therapeutic spa in the neighbourhood of Baiae actually at Tritoli (Fig. 1) - which advertize the curative powers of the waters by pointing to their diseased organs. According to Conrad these figures were made of gypsum; and he also described another set of figures in similar stances, which Kauffmann has inferred

${ }^{15}$ Epistola Conradi cancellarii, ed. Lappenberg (above, n. 8), XXI. 195. 'Ibidem' refers to Baiae in the previous sentence to be quoted below, at n. 17, where Conrad described some Baian baths. However, the reader should be aware of the looseness with which place-names were used in early and late antiquity. The baths which Conrad described as 'Baian' are also called 'Puteolan' by Peter of Eboli in his poem to be quoted shortly below. The geographical designation is fluid due to the territorial extensions of both Baiae and Puteoli (modern Pozzuoli) in different periods. Thus both authors, although they use different geographical designations, were describing the same baths. And both geographical terms take in the region of Avernus. To illustrate further the matter in question, Suetonius, Aug. 16 referred to the above mentioned Portus Julius created out of the Avernian lake as being 'at Baiae' (apud Baias), where at the lakeside Conrad, also referring to Baiae, must have placed the Sibyl's dwelling - her Cumaean cave being no longer accessible in Conrad's day. 
must have been depicted, by contrast, in murals. ${ }^{16}$ Conrad described the baths and the figures thus: ${ }^{17}$ 'Sunt in vicino loco Baie ... balnea ... Inter que balnea unum est principale et maximum, in quo sunt ymagines, hodierno tempore vetustate consumpte, singulas singularum partium corporis passiones demonstrantes. Sunt et alie ymagines gypsee singule singula balnea demonstrantes singulis passionibus profutura'.

On the sculptured figures Petrarch wrote: ${ }^{18}$ 'Vidi non cryptam modo, que Neapolitana dicitur, cuius ad Lucilium scribens meminit Anneus Seneca, sed passim perforatos montes atque suspensos testudinibus marmoreis eximio candore fulgentibus, et insculptas imagines, quis latex cui corporis parti faveat, manu apposita designantes'. The crypta Neapolitana, about which Petrarch was aware that Seneca wrote in Epist. ad Luc. 57. 1.2, was cut through the northern end of Posillipo between the church of Santa Maria di Piedigrotta and Fuorigrotta to take the new via Puteolana, constructed in the Augustan age as an alternative, quicker route between Pozzuoli and Naples than the old ria Antiniana. ${ }^{19}$ Petrarch did not see the sculptures in this tunnel, however. By 'hollowed vaulted mountains everywhere' he referred to the series of spas cut into the rocks at Tritoli. ${ }^{20}$ Petrarch also gave a passing mention to these baths as the "marmoree testudines calidis fontibus superiecte' in the Itinerarium Syriacum. ${ }^{21}$

Some 25 years after Conrad and 123 before Petrarch, the Italian versifier Peter of Eboli depicted the same sculptured figures in his Latin poem De Balneis Puteolanis, 'On the Baths of Puteoli', composed in elegaics about 1220. Peter confirmed that Tritoli was their location, since he described them, under the heading 'De Balneo quod Tritulus dicitur', as follows: ${ }^{22}$

Est locus antiqua testudine ductus in alvum, Rupe sub ingenti celte cavata domus.

Plena figuratis morborum conscia formis Ad quid aque valeant queque figura notat.

Whether Petrarch had read Peter as well as Conrad must be an open question, on which see further in the next section.

${ }^{16}$ C.M. Kauffmann, The Baths of Pozzuoli: A Study of the Medieval Illuminations of Peter of Eboli's Poem (Oxford, 1959), 59.

${ }^{17}$ Epistola Conradi cancellarii, ed. Lappenberg (above, n. 8), XXI. 194-5.

${ }^{18}$ Petrarch, Fam. 5. 4, ed. Rossi (above, n. 4), II.11-12 (= Basle 1554 ed., Opera, II. 713). For further argumentation identifying the baths housing the sculptured figures see below, n. 20 .

${ }^{19}$ According to Strabo 5. 4.5, Cocceius built this tunnel and the Grotta di Cocceio, as in all probability he did the Grotta di Seiano through the southern extremity of Posillipo, as well as the other two tunnels mentioned earlier in this article. An extensive bibliography collected by J.W. Spargo, Virgil the Necromancer: Studies in Virgilian Legends (Cambridge (Mass.), 1934), 444-6, attests to the popular belief that the crypta Neapolitana was created by Vergil the sorcerer, which Petrarch (above, n. 12) rejected.

${ }^{20}$ Petrarch prefaced the passage quoted at $n .18$ with this more obvious mention of the baths: 'Vidi rupes undique liquorem saluberrimum stillantes, et cuntis olim morborum generibus omniparentis nature munere adhibita ... balnea'. The phrase 'passim perforatos montes atque suspensos' quoted at $\mathrm{n} .18$ therefore refers back to 'rupes', and Petrarch's mention there of the crypta Neapolitana merely illustrates the meaning of 'perforatos' but is otherwise a geographical interruption.

${ }^{21}$ Ed. Lo Monaco (above, n. 5), 56.

${ }^{22}$ Vss. 241-4, taken from an edition I am preparing of Peter's poem with slightly different punctuation here from J.M. D'Amato, Prolegomena to a Critical Edition of the Illustrated Medieval Poem De balneis Terre Laboris by Peter of Eboli (Ph.D. dissertation, Johns Hopkins, 1975), 433 (which refers to Peter's poem by an alternative title). 


\section{THE SIBYL'S AVERNIAN HOME}

At the end of my paper I raised the possibility (not considered by Feo) that Petrarch also derived from Conrad the idea that the Sibyl dwelt apart from the catabatic cave at Avernus. That Petrarch depicted them apart is evident from two of his letters. In Fam. 5 . 4 Petrarch saw the 'Sibyl's dwelling and that awesome cave without return for the foolish and without access for the wise'. The 'and' here indicates separate monuments. In Metr. II. 15.30-35 Petrarch described the Sibyl's dwelling as follows:

Proxima fatiloquae domus est habitata Sibyllae;
sulphureoque gravis moles impendet Averno
fessa aevo, metuenda situ. Centum ostia vocum
vatis apollineae, partim sub strage ruinae
sparsa iacent; partim solido se limine servant;
muta tamen: siluere Dei, siluitque sacerdos.

The 'monument' (moles) which 'overlooks Avernus' is not only the 'prophetic Sibyl's home' (fatiloque domus ... Sibyllae). It has a 'hundred openings' (centum ostia) for the 'voices' (vocum) of the Sibylline prophetess corresponding to 'the hundred openings' bearing as many 'voices' which the Sibyl sends forth from her oracular cave at Aen. 6 . 43-4. Petrarch added that the monument's hundred openings now laid partly in ruins, though their 'threshold' (limine, cf. Aen. 6. 45) remained.

The importance of this passage is that in it Petrarch identified the Sibyl's prophetic cave (at Cumae), as described by Vergil, with her 'home'. Clearly Petrarch took notice of Vergil's distinction, which is reflected in Servius's commentary on Aen. 6. 237, between the Cumaean cave of prophecy, which Vergil said was her 'home' (domus) at Aen. 6.53 and 6. 81, and the cave of descent at Avernus - save that Petrarch placed both at the lakeside and identified the former with the thermal building (as will be confirmed immediately below), which is not a cave. Petrarch then followed this passage with a reference to lake Avernus's dark water (echoing Aen. 6. 238 quoted in section 1 above) and the description of the infernal cave within Mons Barbarus. No doubt Petrarch's appreciation of the distinction between the place of prophecy and descent allowed him to accept Conrad of Querfurt's portrayal of the Sibyl as dwelling apart from the cave of descent, though Conrad, as we have seen, came to this idea from quite different considerations.

Petrarch's distinction between the awesome cave of no return and the Sibyl's home is repeated in the Itinerarium Syriacum, where Petrarch depicted the Cumaean Sibyl as dwelling in her 'huge home visible above the awesome bank of the water'. About this monument, already described in Metr. II. 15.30-5, Petrarch was most specific - "it is visible above the awesome bank of the water, and now half-ruined through decay, there being no inhabitant, it is the much frequented nesting place of different birds' (Latin text quoted above at n. 5). This brief account of the monument can apply to neither the Grotta della Sibilla nor the Grotta di Cocceio, but it aptly describes the huge domed thermal establishment whose imposing structure still dominates the lake from its eastern corner (Fig. 1). ${ }^{23}$ Petrarch may have regarded this bath-building as the Sibyl's domus because Conrad remarked that the Sibyl's dwelling or 'palace' has 'the Sibyl's bath' within it (for the Latin text see above at n. 15) and Petrarch understood Conrad to have referred to this thermal building. Perhaps Conrad did. But Conrad's description of the

${ }^{23}$ On this bath-building see M. Pagano and J. Rougetet, 'Le grandi terme dette 'Tempio di Apollo' sul Iago di Averno', Puteoli 12-13 (1988-9), 151-209. 
Sibyl's palace 'constructed with its elaborate rooms wherein the Sibyl had her bath' can also be understood as a plausible description of the series of subterranean rooms with hot-spring in the Grotta della Sibilla. ${ }^{24}$

As chance has it, the half-ruined thermal building twice described by Petrarch was also described by Peter of Eboli, who told us that it was already in ruins in his day. Several medieval illustrated manuscripts of Peter's poem show that its dome had collapsed. Peter, however, giving this hot spring its medieval name 'De Ferris', is at variance from Petrarch in his view of it:

Ante domum vatis, lacus est ubi dictus Averni, Grande ruinose preminet artis opus.

$$
\text { (vss. 205-6) }
$$

Here Peter specifically differentiated this bath building from the 'Sibyl's home' (domum vatis), which he said lay 'in front of' (ante) it. Peter, in short, used the Grotta della Sibilla on the other side of the lake as the reference point and the means by which to indicate where the domed spa building was situated. In doing so Peter reflected the traditional view that the Grotta della Sibilla, which Servius regarded as the catabatic cave, was also the Sibyl's 'home'. From this tradition Petrarch, keeping Vergil in mind and taking a hint from Conrad, who may or may not have identified the Sibyl's 'palace' and 'bath' with the bath-building rather than with the Grotta della Sibilla, is the exception. ${ }^{25}$

There is one more piece of testimony to consider pertaining to Petrarch's probable use of sources for the scene at Avernus. In a late recension of Peter's poem, the Avernian Sibyl's cave was called 'Palumbara' and was said to be so called because, with a word-play on its name, it was a 'welcome nesting place for doves' (cripta ... grata palumbis). How tradition turned the alleged catabatic cave at Avernus into the Cumaean Sibyl's 'home' and then introduced within the Sibyl's Avernian home her 'bath', and how the Grotta della Sibilla came to be called by the name 'Palumbara', are issues dealt with in my article devoted to the cultural history of the Grotta della Sibilla. ${ }^{26}$ But could it be from this description of the Grotta as Palumbara, rather than from observation alone, that Petrarch took the idea that the bath-building, once in his view the home of the Sibyl, was now the 'much frequented nest of different birds' (Latin text above at n. 5)? If so, Petrarch's description of the Avernian region was influenced by Peter of Eboli as well as by Servius and Conrad of Querfurt. ${ }^{27}$

${ }^{24}$ For a plan of and discussion on the rooms and the spring in the 'Grotta', see M. Pagano, M. Reddé and J.M. Roddaz, 'Recherches archéologiques et historiques sur la zone du lac d'Averne', Mélanges de l'Ecole Francaise de Rome. Antiquité 94 (1982), 271-323, esp. pp. 297-319. The plan is reproduced along with photographs in Amalfitano, Camodeca and Medri, I Campi Flegrei (above, n. 11), 174-7.

${ }^{25}$ That this is not realized can be neatly illustrated from Pierre de Nolhac, Erasme en Italie: Étude sur un épisode de la Renaissance suivie de douze lettres inédits d'Érasme (Paris, 1894 and new edition 1898), 83-4. This author here pointed out (citing Beatus Rhenanus, Vie d'Érasme, from Vilae selectorum aliquot virorum ed. G. Bates (London, 1681), 198-201) that Erasmus too, on his second journey to Naples, wished to see the 'Sibyl's cave'. De Nolhac believed that this cave was in all probability not the Sibyl's cave on the Cumaean acropolis but the 'bagno della Sibilla, près du lac Averne', as described by Petrarch in the Itinerarium Syriacum. The 'Sibyl's bath' in Petrarch is, of course, not a cave, and - for the reason given above at the end of n. 15 - Erasmus was almost certainly referring to the Grotta della Sibilla beside Avernus.

${ }^{26}$ See Clark, 'The Avernian Sibyl's Cave' (above, n. 2), passim.

${ }^{27}$ For his skill and patience in designing the accompanying map I am greatly indebted to Gary McManus, the cartographer in Memorial University of Newfoundland's cartographic laboratory. For support of my research I am grateful to the Social Sciences and Humanities Research Council of Canada. 